\title{
Diversity of Mammomonogamus (Nematoda: Syngamidae) in large African herbivores
}

\author{
Barbora Červená ${ }^{1}$ (D) Kristýna Hrazdilová $^{2,3}$ - Peter Vallo ${ }^{4,5} \cdot$ Barbora Pafčo $^{1} \cdot$ Tereza Fenyková $^{1}$. \\ Klára Judita Petrželková ${ }^{4,6,7}$. Angelique Todd ${ }^{8} \cdot$ Nikki Tagg $^{9} \cdot$ Nadege Wangue $^{10}$ • Estevam G. Lux Hoppe ${ }^{11}$. \\ Marcela Figuerêdo Duarte Moraes ${ }^{11}$. Ivan Moura Lapera ${ }^{11}$. Andressa de Souza Pollo ${ }^{11}$. \\ Ana Cláudia Alexandre de Albuquerque ${ }^{12}$. David Modrý ${ }^{1,2,6}$
}

Received: 29 August 2017 / Accepted: 22 January 2018 / Published online: 22 February 2018

(C) Springer-Verlag GmbH Germany, part of Springer Nature 2018

\begin{abstract}
Four species of Mammomonogamus are known from large African herbivores. A recent study demonstrated that a single Mammomonogamus species was shared by both western lowland gorillas (Gorilla gorilla gorilla) and African forest elephants (Loxodonta cyclotis) in Central African Republic, suggesting lower species diversity than previously described in literature. We examined more than 500 fecal samples collected from sympatric African forest elephants, western lowland gorillas, and African forest buffaloes (Syncerus caffer nanus) at four study sites across Central Africa and examined them by coproscopic methods to detect Mammomonogamus eggs, which were found at three of the study sites. Subsequently, sequences of 18S rDNA, 28S rDNA, and cox 1 amplified from individual eggs were analyzed. Phylogenetic analyses of both nuclear and mitochondrial DNA revealed two clades: one formed by sequences originating from Gabonese buffaloes and the other comprising gorillas and elephants. The gorilla-elephant clade was further differentiated depending on the locality. We show the existence of at least two distinct species of Mammomonogamus, M. loxodontis in elephants and gorillas and M. nasicola in buffaloes. The available information on Mammomonogamus in African herbivores is reviewed.
\end{abstract}

Keywords Mammomonogamus · Gorilla $\cdot$ African forest elephant $\cdot$ African forest buffalo $\cdot$ Parasite sharing $\cdot$ Host specificity

Section Editor: Julia Walochnik

Electronic supplementary material The online version of this article (https://doi.org/10.1007/s00436-018-5777-y) contains supplementary material, which is available to authorized users.

Barbora Červená

bara.cervena@gmail.com

1 Department of Pathology and Parasitology, Faculty of Veterinary Medicine, University of Veterinary and Pharmaceutical Sciences Brno, Palackého tř. 1946/1, 61242 Brno, Czech Republic

2 Central European Institute for Technology (CEITEC), University of Veterinary and Pharmaceutical Sciences, Palackého tř. 1946/1, 612 42 Brno, Czech Republic

3 Department of Virology, Veterinary Research Institute, Hudcova 296/ 70, 62100 Brno, Czech Republic

4 Institute of Vertebrate Biology, Czech Academy of Sciences, Květná 8, 60365 Brno, Czech Republic

5 Evolutionary Ecology and Conservation Genomics, University of Ulm, Albert Einstein Allee 11, 89069 Ulm, Germany
6 Institute of Parasitology, Biology Centre of the Czech Academy of Sciences, Branišovská 31, 37005 České Budějovice, Czech Republic

7 Liberec Zoo, Lidové sady 425/1, 46001 Liberec, Czech Republic

8 WWF, Dzanga-Sangha Protected Areas, BP 1053 Bangui, Central African Republic

9 Projet Grands Singes, Centre for Research and Conservation, Royal Zoological Society of Antwerp, Koningin Astridplein 20-26, 2018 Antwerpen, Belgium

10 WWF Kudu-Zumbo Programme, Campo, Cameroon

11 Universidade Estadual Paulista-UNESP, Faculdade de Ciências Agrárias e Veterinárias, Câmpus de Jaboticabal, Via de Acesso Prof. Paulo Donato Castelane, S/N, Jaboticabal, SP 14884-900, Brazil

12 Veterinary Medicine and Animal Science School, UNESP — São Paulo State University, Rua Prof. Doutor Walter Mauricio Correa, S/N, Botucatu, São Paulo 18618-000, Brazil 


\section{Introduction}

Many pathogens, including parasitic helminths, are capable of infecting multiple host species and, similarly, one host can be infected by multiple parasites (Woolhouse et al. 2001; Walker et al. 2017). The spectrum of host species at each stage of parasite's life cycle is one of the most fundamental characteristics of host specificity, the main hallmark of a true species trait (Poulin 2007a). Although host specificity has important implications for human health, animal husbandry, and wildlife conservation (Herd 1986; Martin et al. 2011; Cooper et al. 2012; Standley et al. 2013; Hasegawa et al. 2014), this knowledge is lacking for most parasite taxa. While most past studies have focused on one-host-one-parasite models, contemporary research on parasite ecology addresses the relationships within communities in multi-parasite and multi-host systems, thus reflecting the real situation in nature (Telfer et al. 2010; Johnson et al. 2015; Walker et al. 2017; Webster et al. 2017). Even though host switching is more probable among phylogenetically related host species, it is far from impossible even among phylogenetically distant hosts (Poulin 2007a; Cooper et al. 2012; Walker et al. 2017).

On the African continent, four species of the genus Mammomonogamus parasitize the respiratory tract of a number of large herbivores and primates, including the African forest elephants Loxodonta cyclotis, Matschie (1900); western lowland gorillas Gorilla gorilla gorilla Savage \& Wyman (1847); African forest buffaloes Syncerus caffer nanus, Boddaert (1785); okapis Okapia johnstoni, Sclater (1901); hippopotamuses Hippopotamus amphibius, Linnaeus (1758); African buffaloes Syncerus caffer, Sparrman (1779); mandrills Mandrillus sphinx, Linnaeus (1758); and several antelope species and domestic ruminants (von Linstow 1899; Gedoelst 1924; Ghesquière 1934; Vuylsteke 1935; van den Berghe 1937; Sachs and Sachs 1968; Sachs and Debbie 1969; Sachs et al. 1969; Graber et al. 1971; Graber et al. 1972; Vercruysse 1978; Opasina and Dipeolu 1983; Freeman et al. 2004; Kinsella et al. 2004; Setchell et al. 2007; Červená et al. 2017) (Fig. 1). All the African species of Mammomonogamus have been described based solely on adult worm morphology (von Linstow 1899; Gedoelst 1924; Vuylsteke 1935; van den Berghe 1937; Table 1) and with the host species considered as one of the major criteria for defining a new species. However, although morphological species' descriptions remain essential, estimates of host specificity based solely on the parasite morphological identification are fast losing their validity, and the specificity of most parasite taxa needs to be reassessed based on both morphological and genetic and/or experimental data (Poulin and Keeney 2008; Budischak et al. 2012; Streicker et al. 2015).

In our recent study (Červená et al. 2017), we provided evidence for a single Mammomonogamus species, tentatively referred to as M. loxodontis (Vuylsteke, 1935), being shared by sympatric African forest elephants and western lowland gorillas in Dzanga Sangha Protected Areas in Central African Republic. Such results suggest the real diversity of African Mammomonogamus species to be lower than the number of nominal taxa described from various hosts. Simultaneously, these results raised the question of diversity and host specificity of Mammomonogamus of herbivores in multi-host systems in other African localities. In the present study, we first reviewed the information on African Mammomonogamus species. Second, in an attempt to answer persisting and newly emerging questions, we investigated occurrence and genetic diversity of Mammomonogamus in a broader set of samples obtained from study sites in Cameroon, Gabon, and Central African Republic, where African forest buffaloes, lowland gorillas, and forest elephants live in sympatry. Phylogenetic analyses of sequences of both nuclear and mitochondrial markers revealed a range of haplotypes clustering into three subclades, clearly differing from the reference sequence of Mammomonogamus laryngeus. The number of putative species is discussed and compared to intraspecific variability found in related ancylostomatid and syngamid nematodes.

\section{Material and methods}

\section{Study sites, sampling, and coproscopic examination}

Material was obtained from three study sites in Gabon and Cameroon (Fig. 1), listed as follows:

\section{(1) Loango National Park (LNP), Gabon}

The samples were collected in a $\pm 24,000$ ha private ecotourism concession under development, situated on the Atlantic coast ca $150 \mathrm{~km}$ south of Port-Gentil from May to July 2014. The character of the habitat is described in Morgan (2007) and Head et al. (2013).

\section{(2) Campo Ma'an National Park (CMNP), Cameroon}

The CMNP is situated on the south of Cameroon on the border with the Republic of Equatorial Guinea. The samples were collected in the northern part of the Dipikar Island $\left(350 \mathrm{~km}^{2}\right)$ in the south-western part of the park from September to October 2013. For more details about the habitat, see Tchouto (2004) and Bekhuis et al. (2008).

\section{(3) Dja Faunal Reserve (DFR), Cameroon}

The DFR is situated in southeast Cameroon. Samples were collected in ca $30 \times 30 \mathrm{~km}$ area on the northern periphery of DFR between the villages of Doumo Pierre and Mimpala and 


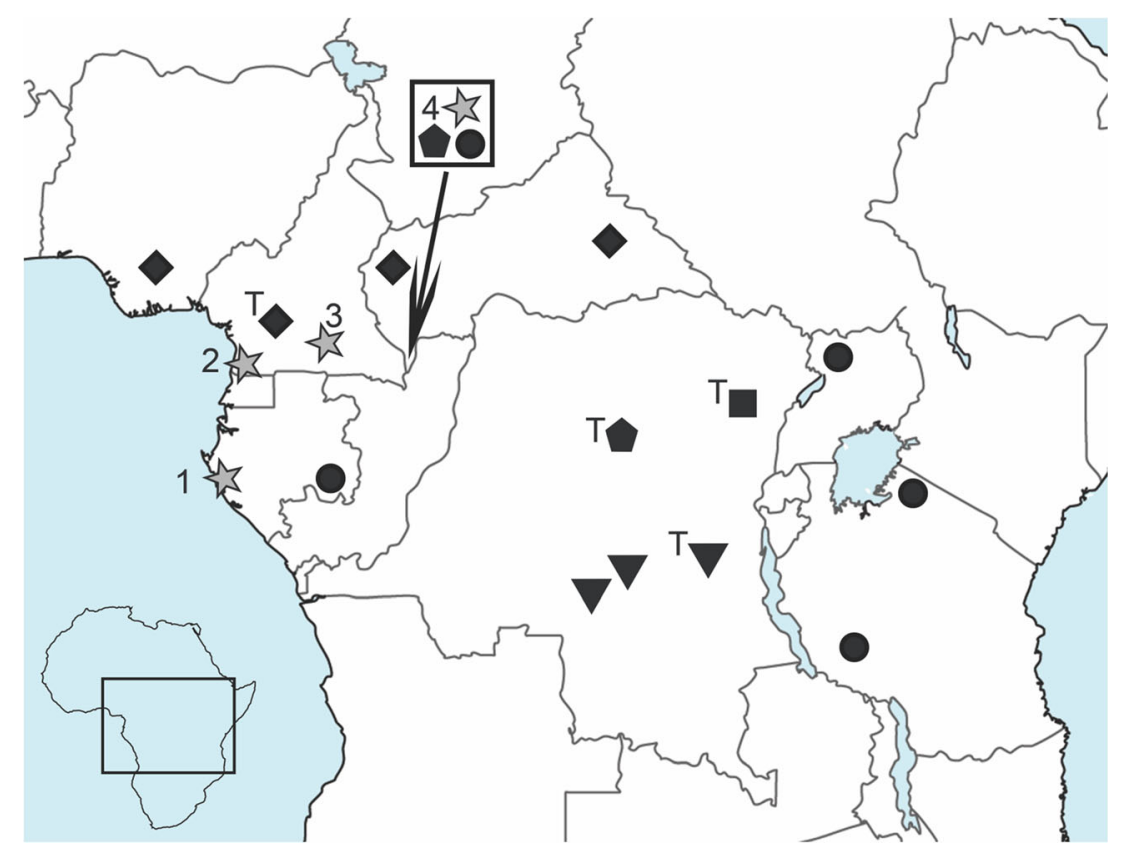

Fig. 1 Distribution of Mammomonogamus spp. in Africa. Mammomonogamus sp. Undetermined adults were found in several antelope species, African buffalo, and African elephant in Uganda and Tanzania (Sachs and Sachs 1968; Sachs and Debbie 1969; Sachs et al. 1969); eggs were found in feces of western lowland gorilla and African forest elephant in DSPA (Freeman et al. 2004; Kinsella et al. 2004) and mandrills in Gabon (Setchell et al. 2007). $\bigcirc=$ M. nasicola (von Linstow 1899). Type specimens (T) were described from a domestic goat in Yaoundé, Cameroon; later, it was recorded in African forest buffalo in eastern Central African Republic (CAR; Graber et al. 1971), in zebu in western CAR (Vercruysse 1978), and in sheep in Southern Nigeria (Opasina and Dipeolu 1983). $\nabla=M$. hippopotami (Gedoelst

the research camp La Belgique from August to October 2014. Habitat composition of the area is characterized in Willie et al. (2012; 2013).

Samples from the three sites under investigation were supplemented with samples collected from habituated gorillas and wild forest elephants collected in the Dzanga-Sangha Protected Areas (DSPA), Central African Republic, in which the 18S rDNA and coxl sequences were already analyzed (Červená et al. 2017). These samples were used to obtain 28S rDNA sequences for analyses in the present study, and Mammomonogamus prevalence values were added for comparison with other sites. Fecal samples of wild forest buffaloes from the same locality were examined in the present study.

Fecal samples (not older than $12 \mathrm{~h}$ ) of unhabituated gorillas were collected from nest sites and/or opportunistically on the forest trails (LNP, DFR, CMNP). Fecal samples of elephants (LNP, DFR) and buffaloes (LNP, DSPA) were collected opportunistically during regular patrol by the research teams and/or trackers and rangers (Supplementary materialTable S1). Maximum effort was made to prevent resampling of same individuals; however, occasional resampling of the same individual cannot be ruled out. The
1924). Originally described in Nyangwé, Democratic Republic of the Congo (DRC), later found around Lusambo and Kananga (Ghesquière 1934). M. loxodontis (Vuylsteke, 1935). Recorded in the Yangambi DRC for the first time and most probably the species infecting gorillas and elephants in DSPA (Červená et al. 2017). = M. okapiae (van den Berghe, 1937). Recorded only in Epulu, DRC. $\{$ = study site. 1 Loango National Park, Gabon; 2 Campo Ma'an National Park, Cameroon; 3 Dja Faunal Reserve, Cameroon; 4 Dzanga Sangha Protected Areas, Central African Republic

samples were divided in two subsamples immediately preserved by addition of $10 \%$ formalin and $96 \%$ ethanol in the ratio of $1 \mathrm{~g}$ of feces to $2 \mathrm{~mL}$ of preservative and stored at ambient temperature while in the field. After returning to the laboratory, the ethanol preserved samples were stored at $-20{ }^{\circ} \mathrm{C}$. All samples were examined by two methods. Initially, the formalin-preserved samples were processed using modified Sheather's flotation solution of specific gravity 1.3 (Sheather 1923) with double centrifugation. The sedimentation technique was applied in two modifications: (1) merthiolate-iodine-formaldehyde concentration (MIFC) (JirkůPomajbíková and Hůzová 2015) for gorillas and (2) modified simple sedimentation for buffalo and elephant samples. In the latter case, $1.5 \mathrm{~mL}$ of homogenized feces was centrifuged for $3 \mathrm{~min}$ at $2000 \mathrm{rpm}$, the supernatant was discarded, and the sediment was resuspended in small volume of water and examined. The examination by light microscopy was performed under 100-400× magnification to detect typical Mammomonogamus spp. eggs. These were distinguished from eggs of gastrointestinal nematodes (GIN) based on the 2-3 $\mu \mathrm{m}$-thick striated shell and typically two or more big blastomeres. For the prevalence calculation, samples showing 
Table 1 Four species of Mammomonogamus are known from African herbivores. The morphology is based on Gedoelst (1924), Vuylsteke (1935), van den Berghe (1937), and Graber et al. (1972). There is no unity in the given information, e.g., in some descriptions, the length of the esophagus is given, and in others, only the ratio of the length of esophagus to body length was presented. To compare the data, when needed, the ratios were calculated based on the measurements given. The measurements are in millimeters, if not stated differently.

\begin{tabular}{|c|c|c|c|c|}
\hline & M. nasicola & M. hippopotami & M. loxodontis & M. okapiae \\
\hline \multicolumn{5}{|l|}{ Length } \\
\hline Male & 3.62 & $5-8$ & 9.8 & $2.1-3.4$ \\
\hline Female & 15.06 & $24-34$ & 28 & $10.4-18.8$ \\
\hline \multicolumn{5}{|l|}{ Buccal capsule } \\
\hline \multicolumn{5}{|l|}{ Length } \\
\hline Male & 0.32 & $0.29-0.32$ & - & $0.32-0.41$ \\
\hline Female & 0.38 & 0.35 & 0.65 & $0.32-0.41$ \\
\hline \multicolumn{5}{|l|}{ Width } \\
\hline Male & 0.42 & $0.29-0.32$ & - & $0.3-0.36$ \\
\hline Female & 0.58 & $0.44-0.45$ & 0.65 & $0.35-0.52$ \\
\hline \multicolumn{5}{|l|}{ Esophagus : body ${ }^{\mathrm{a}}$} \\
\hline Male & 0.23 & $0.11-0.14$ & - & $0.11-0.14$ \\
\hline Female & 0.07 & 0.05 & 0.07 & 0.04 \\
\hline Vulva : body ${ }^{\mathrm{b}}$ & 0.18 & 0.26 & 0.22 & 0.24 \\
\hline Tail & 0.25 & $0.42-0.56$ & 0.37 & $0.22-0.26$ \\
\hline Teeth & 8 & - & 6 & 8 \\
\hline Ribs & 6 & $6+2$ dentiform & 6 & 6 \\
\hline Papillae cephalicae & 6 & 6 & - & - \\
\hline \multicolumn{5}{|l|}{ Spicules } \\
\hline \multicolumn{5}{|l|}{ Eggs } \\
\hline Length $(\mu \mathrm{m})$ & $78.9-91.2$ & $104-108$ & 100 & $68-82$ \\
\hline Width $(\mu \mathrm{m})$ & $51.3-60.8$ & $56-58$ & 57 & $42-49$ \\
\hline Site of infection & Trachea, epiglottis, nasal cavity & Nasal cavity & Trachea & Trachea, bronchi \\
\hline
\end{tabular}

the presence of Mammomonogamus eggs in at least one method were scored as positive.

\section{Comparative material}

Adults of $M$. laryngeus were collected from a water buffalo Bubalus bubalis, Linnaeus (1758) at a slaughterhouse in the municipality of Soure (Pará state, Brazil). Several Syngamus nematodes were collected from common blackbird Turdus merula, Linnaeus (1758) and carrion crow Corvus corone, Linnaeus (1758) in the Czech Republic and Cyathostoma cf. bronchialis, Mühling (1844) from domestic goose from Slovakia (Supplementary material-Table S1). These samples were preserved in $96 \%$ ethanol until DNA extraction.

\section{DNA extraction, PCR, and sequencing}

DNA extraction from mechanically disrupted single eggs was performed using Genomic DNA Mini Kit GT300 (Tissue) (Geneaid, New Taipei City, Taiwan) as described previously (Červená et al. 2017). Partial sequences of cytochrome c oxidase subunit I $(\operatorname{cox} 1), 18 \mathrm{~S}$ rDNA, and $28 \mathrm{~S}$ rDNA were amplified.
Partial sequences of coxl and 18S were amplified in multiplex PCR using the primers NC18SF1, NC5BR, LCO1490, HCO2198, coxmamF, and coxmamR (Folmer et al. 1994; Chilton et al. 2006; Červená et al. 2017) in $25-\mu \mathrm{L}$ reaction mixtures containing $12.5 \mu \mathrm{L}$ of Phusion $\circledR$ High-Fidelity PCR Master Mix HF Buffer (New England Biolabs, Ipswich, UK), $0.5 \mu \mathrm{M}$ of each primer, and $3 \mu \mathrm{L}$ of template DNA. PCR conditions were as follows: initial denaturation at $98{ }^{\circ} \mathrm{C}$ for $30 \mathrm{~s}$ followed by 35 cycles of $98^{\circ} \mathrm{C}$ denaturation for $10 \mathrm{~s}$, $55^{\circ} \mathrm{C}$ annealing for $30 \mathrm{~s}$, and $72{ }^{\circ} \mathrm{C}$ elongation for $1 \mathrm{~min}$ with final post-amplification elongation for $7 \min$ at $72{ }^{\circ} \mathrm{C}$. One $\mu \mathrm{L}$ of PCR product was then used as a DNA template for a second PCR round where both markers were amplified separately by using the same polymerase and conditions as in the first round. We used primers NC18SF1 and NC5BR for 18S and different combinations of LCO1490, HCO2198, coxmamF and coxmamR for coxl.

Partial 28S rDNA was amplified using NC2R and NC28R primers (Chilton et al. 2003) following the same PCR protocol as in Červená et al. (2017). In some cases, NC28R reverse primer was replaced by NC28-12R (Chilton et al. 2003). Then, the $25-\mu \mathrm{L}$ PCR mixtures were of the same composition as described above for the second round of PCR for $18 \mathrm{~S}$ and 
coxl amplification. PCR conditions were the same as for $18 \mathrm{~S}$ and coxl, but the annealing temperature was $60^{\circ} \mathrm{C}$. When low quality sequences were obtained, PCR products were cloned using p-GEM®-T Easy Vector System (Promega, Madison, US).

DNA from adult helminths was isolated using Genomic DNA Mini Kit GT300 (Tissue) (Geneaid, New Taipei City, Taiwan). The DNA of M. laryngeus was amplified using the same approach described for DNA originating from eggs. In the case of Syngamus spp., parts of 18S rDNA, 28S rDNA, and cox 1 were amplified using primer pairs NC18SF1, NC5BR (Chilton et al. 2006); NC2R, NC28R (Chilton et al. 2003); and LCO1490, HCO2198 (Folmer et al. 1994), respectively. The $25-\mu \mathrm{L}$ PCR reaction mixture contained $12.5 \mu \mathrm{L}$ of PPP Master Mix (Top-Bio, Prague, Czech Republic), $0.8 \mu \mathrm{M}$ of each primer (10) and $1 \mu \mathrm{L}$ of template DNA. PCR conditions were the same for all DNA markers: initial denaturation at $94{ }^{\circ} \mathrm{C}$ for $1 \mathrm{~min}$, followed by 35 cycles of $94{ }^{\circ} \mathrm{C}$ denaturation for $40 \mathrm{~s}, 50^{\circ} \mathrm{C}$ annealing for $40 \mathrm{~s}, 65^{\circ} \mathrm{C}$ elongation for $40 \mathrm{~s}$, followed by a $5 \mathrm{~min}$ post-amplification extension at $65^{\circ} \mathrm{C}$.

The PCR products were separated in $2 \%$ agarose gel, visualized by GoodView ${ }^{\mathrm{TM}}$ Nucleic Acid Stain (Ecoli s.r.o., Bratislava, Slovakia) and detected using an UV illuminator. PCR products were purified either directly or from the gel using Gel/PCR DNA Fragments Extraction Kit (Geneaid, New Taipei City, Taiwan). Products were commercially sequenced in both directions by Macrogen (Amsterdam, Netherlands). The nucleotide sequences obtained in this study were submitted to the GenBank under the accession numbers MF667999-MF668042 and MG645004 (Supplementary material-Table S2).

\section{DNA sequence alignment and phylogenetic analysis}

DNA sequences of coxl, 18S rDNA, and 28S rDNA were trimmed, assembled, and manually edited in BioEdit 7.2.3 (Hall 1999) and aligned with implemented ClustalW (Larkin et al. 2007). Phylogenetic information in the datasets was tested by likelihood mapping (Strimmer and Haeseler 1997). Pairwise sequence distances (PSD) were calculated using Geneious 9.1.2 (http://geneious.com, Kearse et al. 2012). Concatenated phylogenetic analysis of $18 \mathrm{~S}$ and $28 \mathrm{~S}$ rDNA sequences was carried out using Bayesian inference (BI) in MrBayes 3.2.2 (Hastings 1970; Ronquist and Huelsenbeck 2003). GenBank sequences of selected strongylids (Chilton et al. 2006; Supplementary material-Table S3) were added into the alignment of $18 \mathrm{~S}$ rDNA and 28S rDNA for comparison. BI was done in two simultaneous runs of four Metropolis-couple Monte Carlo Markov chains of one million generations sampled each 100 generations and $25 \%$ generations discarded as burn-in. The GTR $+\mathrm{I}+\Gamma$ model of sequence evolution used in BI was chosen based on Akaike information criterion computed by Modeltest 3.7 (Posada and Crandall 1998). The coxl sequences were analyzed by BI as well, using the best-fit phylogenetic model GTR + G. Sequences of the same strongylid species included in analysis of nuclear DNA were added to the dataset, if available in the GenBank.

\section{Results}

Altogether, 89 western lowland gorilla from LNP, DFR, and CMNP, 35 African forest elephant from DSPA, LNP, and DFR, and 106 African forest buffalo fecal samples from DSPA and LNP were examined. Numbers of samples examined at each study site and from each host are showed in Table 2. Prevalence of Mammomonogamus differed among the hosts and study sites (Table 2). Eggs of Mammomonogamus were found in gorilla feces in all but one locality (DFR). The prevalence in DSPA and LNP was similar, although the sample size differed. In CMNP, Mammomonogamus eggs were detected in only two of 46 gorilla fecal samples. Eggs of Mammomonogamus were found in elephant fecal samples in DSPA and LNP, but not in DFR. In buffalo feces collected in both LNP and DSPA, eggs of Mammomonogamus were detected. The prevalence in DSPA was much lower and unfortunately, eggs were not found in subsamples preserved in ethanol, thus the molecular analysis could not be performed. The size of Mammomonogamus eggs varied from 90 to $102.5 \mu \mathrm{m} \times 47.5$ to $60 \mu \mathrm{m}$, the surface was slightly striated and the eggs contained $2-8$ blastomeres. No apparent differences in morphology of eggs originating from different hosts or different localities were observed, however no statistical comparison was made.

In total, we managed to amplify the nuclear DNA from 28 eggs of Mammomonogamus isolated from nine gorilla (10 eggs), six elephant (10 eggs), and five buffalo (8 eggs) fecal samples, two adults of C. bronchialis, six adults of Syngamus sp. from three different blackbirds, and one carrion crow, and from two adults of $M$. laryngeus from one water buffalo (Table S1).We obtained 19 new sequences of $1163 \mathrm{bp}$ of $18 \mathrm{~S}$ rDNA from three elephant (6 sequences), four gorilla (5 sequences), and five buffalo ( 8 sequences) samples. All but one sequence were identical with sequences previously obtained from gorillas and elephants from DSPA (Červená et al. 2017). The one sequence, marked as E1-b originating from an elephant fecal sample from LNP, differed in a single substitution. The second sequence obtained from another egg from the same fecal sample (marked as E1-a) was identical with the others. The two sequences of $M$. laryngeus were identical and differed from other Mammomonogamus sequences in 14 or 15 substitutions. Sequences of Syngamus sp. were identical in each host species. C. bronchialis differed in 16 substitutions from the Syngamus sequences. 
Table 2 Overview of presence/ absence and prevalence (in parentheses) of

Mammomonogamus in different hosts at our study sites. Asterisk marks data published in Červená et al. (2017). Number of study site corresponds to the map in Fig. 1

\begin{tabular}{llll}
\hline Study site & Elephant & Gorilla & Buffalo \\
\hline 1. Loango National Park & $5 / 18(27.8 \%)$ & $5 / 8(62.5 \%)$ & $19 / 76(25 \%)$ \\
2. Campo Ma'an National Park & - & $2 / 46(2.2 \%)$ & - \\
3. Dja Faunal Reserve & $0 / 17$ & $0 / 35$ & - \\
4. Dzanga Sangha Protected Areas & $12 / 61(19.7 \%)^{*}$ & $139 / 257(54.1 \%)^{*}$ & $2 / 30(6.7 \%)$ \\
\hline
\end{tabular}

The $\sim 684$ bp fragments of 28S rDNA showed higher variability which is summarized in Table 3 . Nine sequences originating from five gorilla (5 eggs) and three elephant (4 eggs) fecal samples from DSPA were identical. Seven sequences obtained from four buffalo samples from LNP were identical, differing from sequences from all gorillas and elephants in eight or nine substitutions. Among the five sequences from three elephant fecal samples from LNP, only one sequence (marked as E2-b) differed by a single substitution; others were identical. Two sequences (marked as G2-b and G3) differing in a single nucleotide were amplified from two gorilla fecal samples from CMNP. One sequence, marked as G1-b, was obtained from a gorilla fecal sample from LNP, and it was identical with the sequence G2-b originating from CMNP and the four identical sequences from elephants from LNP. The difference between the sequence of M. laryngeus and other Mammomonogamus sequences was 38-40 substitutions and 13 insertions/deletions. The variability of the corresponding fragment of 28S rDNA in Syngamus sp. and $C$. bronchialis was low within hosts. The distance between C. bronchialis and Syngamus sp. reached $10 \%$.

Sequences of both $18 \mathrm{~S}$ and $28 \mathrm{~S}$ rDNA were successfully obtained from 15 eggs from 4 buffalo (7 eggs), one gorilla (1 egg), and three elephant (5 eggs) fecal samples from LNP and two gorilla ( 2 eggs) fecal samples from CMNP and were used for subsequent phylogenetic analysis. To reduce the bias in the analysis, identical sequences of Mammomonogamus from gorillas and elephants from DSPA were reduced to two sequences, each representing one host species. Likelihood mapping of the final alignment of $1927 \mathrm{bp}$ of $18 \mathrm{~S}$ rDNA and $28 \mathrm{~S}$ rDNA of 57 taxa showed only $2.2 \%$ of unresolved and $1.3 \%$ partly resolved quartets (Fig. 2). The tree resulting from a concatenated Bayesian inference revealed three clades of African Mammomonogamus (Fig. 3). The first clade is formed by sequences of Mammomonogamus originating from buffaloes from LNP, the second clade includes sequences of Mammomonogamus from gorillas and elephants (LNP, CMNP, DSPA) further subdivided according the locality. Mammomonogamus sequences formed altogether a monophyletic highly supported clade. Sequences of the remaining syngamids, represented by Syngamus and Cyathostoma, cluster in another, well supported clade rather distant from that of Mammomonogamus.

The 375 bp amplicons of cox 1 were successfully obtained from 19 eggs originating from four gorilla (6 eggs), four elephant (5 eggs), and five buffalo (8 eggs) fecal samples. Seven haplotypes of cox 1 already known from gorillas and elephants from DSPA (Červená et al. 2017) were added to the dataset. Two identical sequences were amplified from adults of M. laryngeus. In addition, five sequences of Syngamus sp. were obtained from three blackbirds and one crow and two sequences of $C$. bronchialis from a goose were amplified.

The final alignment, comprising 101 taxa covering obtained sequences and GenBank sequences of species included in the phylogenetic analysis of ribosomal DNA was tested by likelihood mapping which showed $2 \%$ of unresolved and $3.9 \%$ partly resolved quartets. The tree resulting from BI displayed polytomies in deep nodes (Supplementary material - Fig. S4) thus, based on the topography of the phylogenetic tree of $18 \mathrm{~S}$ and $28 \mathrm{~S}$ rDNA, only Mammomonogamus sp. sequences were chosen for the phylogenetic analysis. Five sequences of Necator americanus were used as an outgroup. The tree resulting from the BI showed three distinct clades within the African Mammomonogamus sequences corresponding to the clades described in the analysis of nuclear DNA (Fig. 4). Mammomonogamus laryngeus clustered apart from the African Mammomonogamus clades.
Table 3 Pairwise sequence distances of $28 \mathrm{~S}$ rDNA expressed as number of nucleotides differing. B - buffalo; G - gorilla; E - elephant

\begin{tabular}{llll}
\hline A Mammomonogamus & $\begin{array}{l}\text { Clade B } \\
\text { LNP }\end{array}$ & $\begin{array}{l}\text { Clade G + E } \\
\text { LNP/CMNP }\end{array}$ & $\begin{array}{l}\text { Clade G + E } \\
\text { CAR }\end{array}$ \\
\hline Clade B LNP & 0 & 1 & \\
Clade G + E LNP/CMNP & $8-9$ & $1-2$ & 0 \\
Clade G + E CAR & 8 & Syngamus sp. crow & \\
B Syngamus & Syngamus sp. blackbird & & \\
Syngamus sp. blackbird & $1-4$ & 0 & \\
Syngamus sp. crow & $40-42$ & & \\
\hline
\end{tabular}


Fig. 2 Likelihood mapping of alignment of 57 sequences of $18 \mathrm{~S}$ and $28 \mathrm{~S}$ rDNA. (a) showed only $2.2 \%$ of unresolved and $1.3 \%$ of partly resolved quartets, while the alignment of 101 sequences of coxl (b) showed $2.0 \%$ of unresolved and $3.9 \%$ of partly resolved quartets a

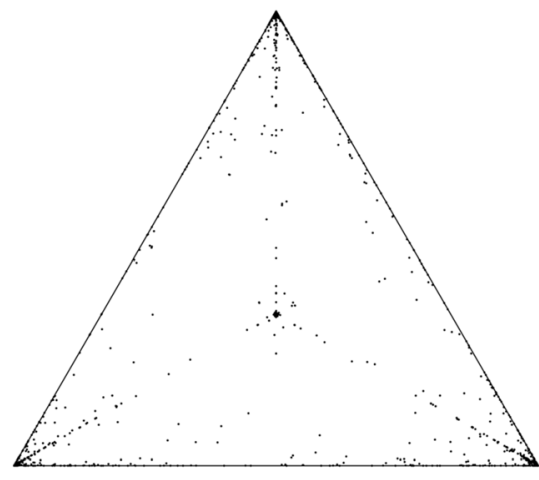

$1927 \mathrm{bp}$

$18 \mathrm{~S}+28 \mathrm{~S}$ rDNA b

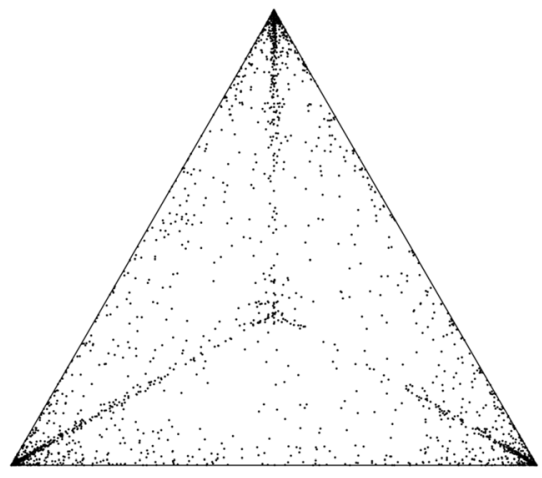

$375 \mathrm{bp}$

$\operatorname{cox} 1$
Within the new 19 African Mammomonogamus sequences, 11 haplotypes could be distinguished. Five haplotypes occurred in buffaloes, differing from each other in one to seven substitutions and represented by one or two sequences. Among the sequences of elephants and gorillas from LNP and CMNP, six haplotypes were discriminated. The most numerous haplotype was represented by five sequences amplified from two elephant and two gorilla fecal samples from LNP, differing from the others in two to six substitutions. The other five haplotypes were represented by one or two sequences. Co-infection by two haplotypes

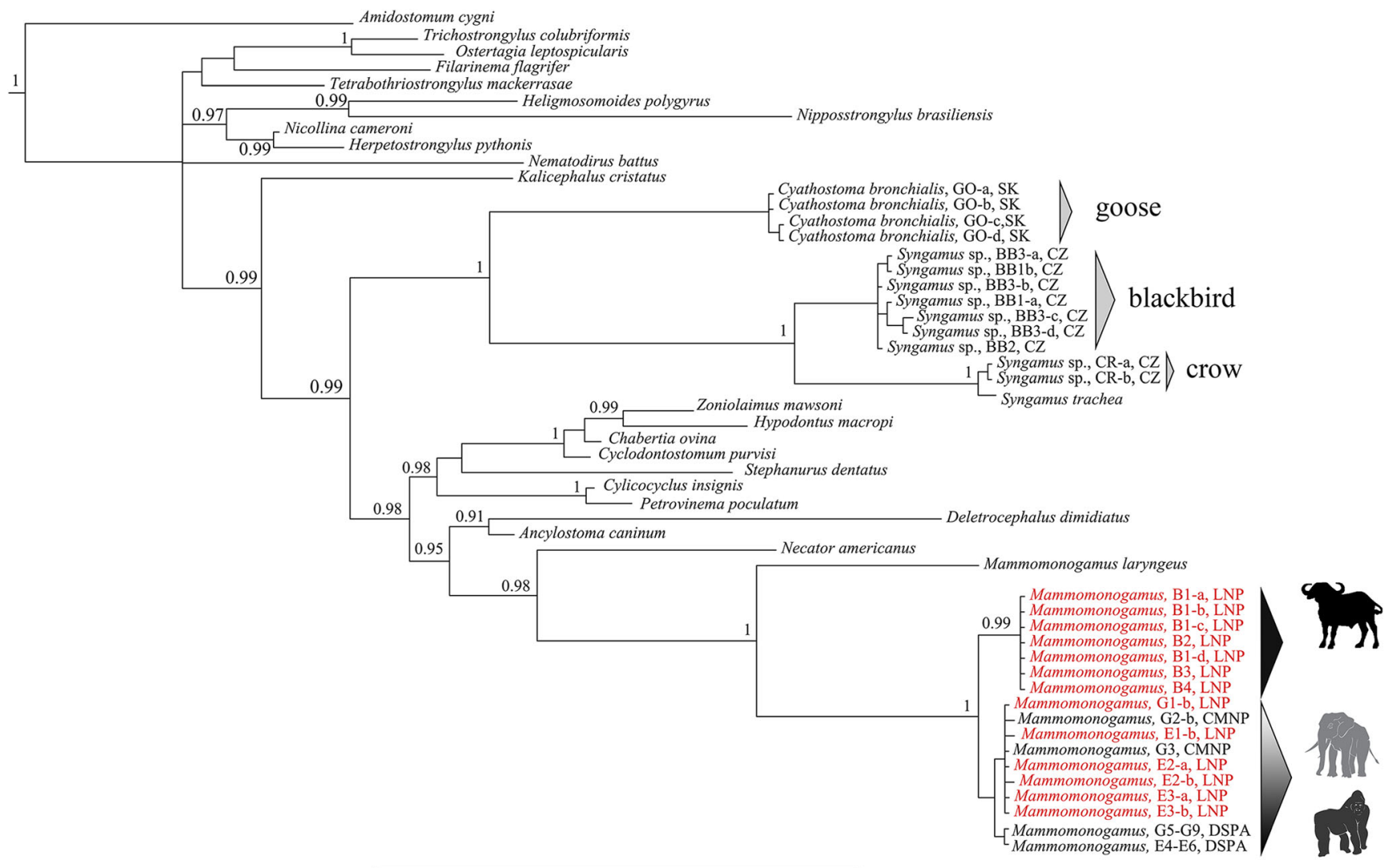

Fig. 3 Phylogenetic tree based on Bayesian inference of concatenated $18 \mathrm{~S}$ rDNA and 28S rDNA sequences. Sequences in red originate from the Loango National Park in Gabon, where African forest buffaloes (B), African forest elephants (E), and western lowland gorillas (G) live sympatrically. Sequences in black were obtained from gorillas and elephants from the Dzanga Sangha Protected Areas (Central African
Republic) and Campo Ma'an National Park (Cameroon). Sequences from Metastrongylus elongatus, Protostrogylus rufescens, and Aelurostrongylus abstrusus used as an outgroup are not displayed. Node-supporting values refer to BI posterior probability (values above 0.9 displayed only) 


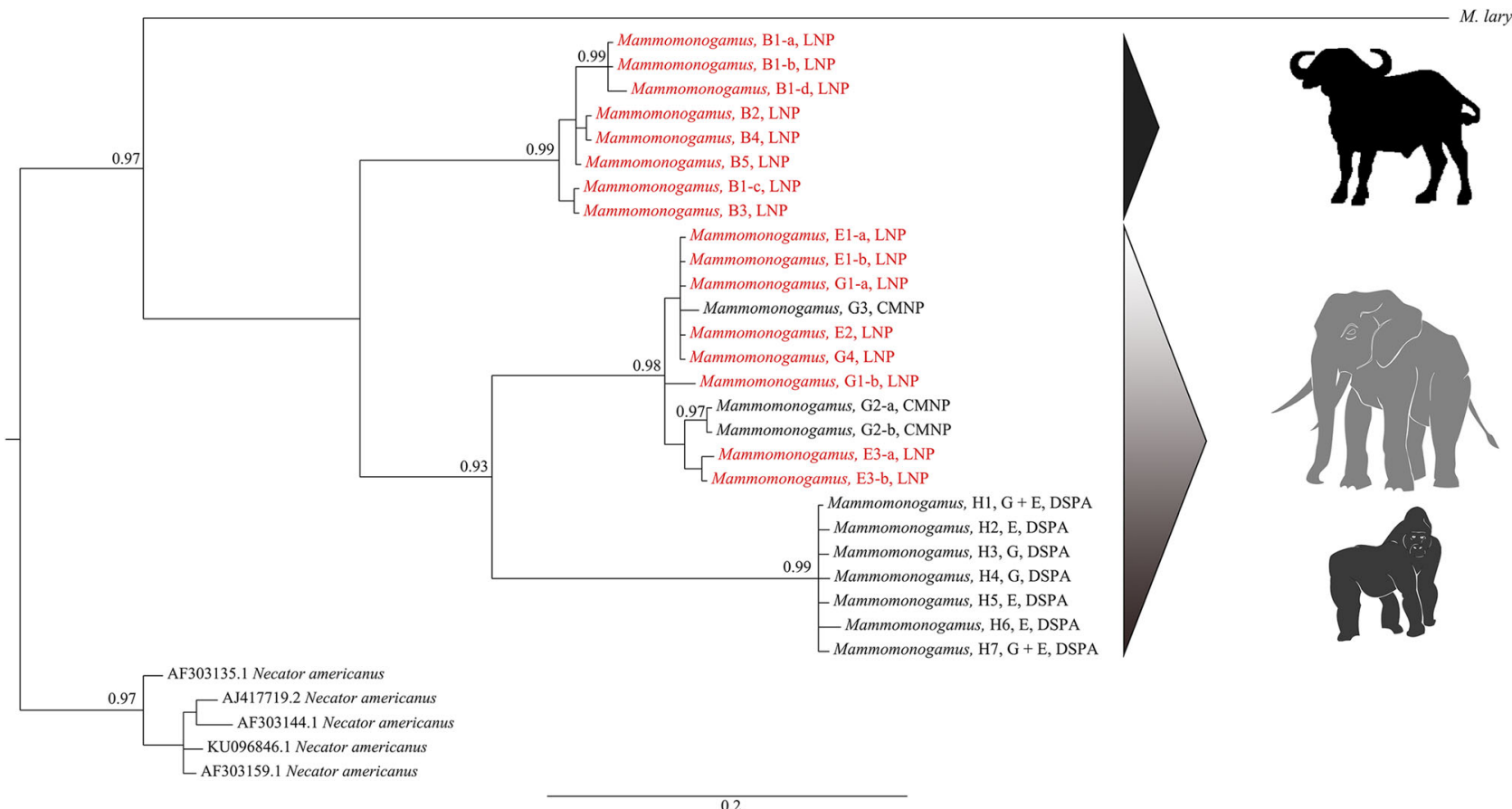

Fig. 4 A phylogenetic tree resulting from Bayesian inference of $375 \mathrm{bp}$ of coxl sequence. Three clades of African Mammomonogamus are formed based on host species and locality. Sequences originating from Loango National Park (Gabon), where all three hosts live sympatrically, are in red.

was found in one gorilla and one elephant sample; three haplotypes were detected in one buffalo fecal sample (Supplementary material-Table S1).

Pairwise sequence distances (PSD) were calculated within and between each Mammomonogamus clade (Table 4a). While the distance inside the clades was very low varying from 0.27 to $2.13 \%$, the distances among all African clades exceeded $10 \%$. The distance between African Mammomonogamus and M. laryngeus was 20.8-23.2\%. For
Black sequences originate from the Campo Ma'an National Park (Cameroon) and Dzanga Sangha Protected Areas (Central African Republic). Node-supporting values refer to BI posterior probability (values above 0.9 displayed only)

comparison, PSD were calculated for syngamids from birds and Ancylostoma spp. (Table 4b, c). The difference between the Syngamus sp. from blackbirds and Syngamus sp. from crow varied around $10 \%$, while the difference between Syngamus sp. from crow and S. trachea from GenBank (number NC_013821.1, originating from an Australian magpie Gymnorhina tibicen Latham, 1802) was only $0.8 \%$. Syngamus sp. sequences differed from $C$. bronchialis in 11.73 to $13.87 \%$.
Table 4 Pairwise sequence distances (PSD; in \% of differences) were calculated for $375 \mathrm{bp}$ of $\operatorname{cox} 1$ within and among the three clades of

Mammomonogamus from Africa (A). PSD of the same part of cox 1 were calculated for Ancylostoma spp. (B) and Syngamus spp. for comparison. B - buffalo;

G - gorilla; E - elephant

\begin{tabular}{lcll}
\hline A Mammomonogamus & $\begin{array}{l}\text { Clade B } \\
\text { LNP }\end{array}$ & $\begin{array}{l}\text { Clade G + E } \\
\text { LNP/CMNP }\end{array}$ & $\begin{array}{l}\text { Clade G + E } \\
\text { CAR }\end{array}$ \\
\hline Clade B LNP & $0.27-1.87$ & & \\
Clade G + E LNP/CMNP & $9.87-11.20$ & $0.27-2.13$ & \\
Clade G + E CAR & $12.8-14.40$ & $11.20-13.07$ & $0.27-1.33$ \\
B Ancylostoma & A. caninum & A. duodenale & A. ceylanicum \\
A. caninum & $0.27-9.07$ & & \\
A. duodenale & $8.27-10.4$ & $1.07-3.47$ & \\
A. ceylanicum & $8.27-9.87$ & $11.20-11.73$ & \\
A. tubaeforme & $9.07-10.67$ & $8.00-8.27$ & \\
C Syngamus & & Syngamus sp. crow & \\
Syngamus sp. blackbird & $1.07-1.60 *$ & & \\
Syngamus sp. crow & $9.60-10.40$ & 0 & \\
S. trachea & $9.60-10.67$ & 0.8 & \\
\hline
\end{tabular}




\section{Discussion}

In our set of samples, Mammomonogamus nematodes appeared to occur broadly among the studied hosts, namely western lowland gorillas, African forest elephants, and African forest buffaloes. We detected typical Mammomonogamus eggs at all but one study site (DFR). At two localities (LNP and DSPA), all three sympatric host species were found to host Mammomonogamus. As the numbers of Mammomonogamus eggs in feces tend to be rather low, it is possible that recorded prevalence values are influenced by false negativity of part of the fecal samples. Our previous study on a group of frequently sampled lowland gorillas in DSPA showed the cumulative prevalence reaching $100 \%$ (Červená et al. 2017).

Despite our expectations, the analysis of $18 \mathrm{~S}$ and $28 \mathrm{~S}$ rDNA and coxl showed diversity of Mammomonogamus among studied hosts and different study sites. Although the $18 \mathrm{~S}$ rDNA sequences were identical in all but one African sample, those of $28 \mathrm{~S}$ rDNA differed markedly. The topology of the Mammomonogamus phylogenetic trees resulting from the analysis of nuclear and mitochondrial DNA markers showed almost identical branching patterns, with sequences of Mammomonogamus from forest buffaloes branching separately from the elephant-gorilla clade and from $M$. laryngeus. Since the genus Mammomonogamus is traditionally assigned to the family Syngamidae, we extended our dataset by comparative sequences of Syngamus spp. and C. bronchialis. Quite surprisingly, the family Syngamidae invariably appeared as paraphyletic in our analyses, while all Mammomonogamus sequences always clustered in a monophyletic, well supported clade. The distinctiveness of Mammomonogamus from other syngamids is further supported by differences in egg morphology. We suggest that the biological and morphological traits used for the definition of Syngamidae may not be true synapomorphies and grouping of current syngamids seems to be rather artificial. Under such a scenario, permanent copulation and affinity to respiratory tract have evolved independently among strongylids parasitizing avian and mammalian hosts. This issue and its reflection in taxonomy should be addressed in future studies.

Rapid evolution of the mitochondrial DNA and high substitution rates (Blouin et al. 1998) makes the coxl gene a suitable marker for analyses of closely related taxa. The cox 1 sequence difference within a single species usually varies from a fraction of a percent up to $2 \%$ with the maximum difference observed between two members of one interbreeding population reaching $7 \%$. In comparison, the difference between two closely related species usually ranges from 10 to $20 \%$ (Blouin et al. 1998; Blouin 2002; Traversa et al. 2008). The pairwise sequence distance (PSD) between the coxl sequences of Mammomonogamus from forest buffaloes and from sympatric gorillas and elephants reaches more than $11 \%$, suggesting a lack of the genetic flow between the two Mammomonogamus populations in sympatric hosts. The PSD in our Syngamus sequences differed in approximately $10 \%$ between those from a crow and blackbirds; however, the difference between the Syngamus sp. from crow and S. trachea from GenBank was only $0.8 \%$, suggesting their conspecificity. Study of coxl sequence diversity within the family Ancylostomatidae (Hu et al. 2002) showed the lowest difference between two distinct species was $4.8 \%$. In our dataset, the differences between separate Ancylostoma species ranged around $10 \%$. However, the PSD within the sequences of $A$. caninum reached more than $9 \%$, which is comparable with previously known data (Hu et al. 2002; Miranda et al. 2008).

The difference between the two clades comprising sequences originating from gorillas and elephants is comparable, implying also the existence of two different Mammomonogamus species common for gorillas and elephants. As parasites during the freeliving stages usually have only limited dispersal capability and the host movements are the main routes for gene flow among the parasite populations, two factors limit the gene flow between any two parasite populations and determine the genetic structure of the parasite metapopulation. First is the geographical distance between populations, and the other is the mobility of the most vagile of the host species used by a parasite for the completion of its life-cycle (Poulin 2007b). Vagility of gorillas and elephants across Central Africa has always been limited by natural barriers (e.g., big rivers); however, the forest fragmentation and poaching pressure nowadays increasingly delimit the home ranges of these species (Blake et al. 2007, Rabanal et al. 2010, Maisels et al. 2013, Fünfstück et al. 2014). Although certain interference of Central African gorilla and elephant populations is beyond any doubt (Clifford et al. 2004; Ishida et al. 2013; Fünfstück and Vigilant 2015), we believe that the observed difference in coxl sequences between elephant-gorilla Mammomonogamus in DSPA and analogous Mammomonogamus in LNP and CMNP results from the geographical distance and disconnectedness of populations of forest elephants and gorillas at these sites. Considering also the data from analysis of nuclear DNA markers, we believe that Mammomonogamus infecting elephants and gorillas throughout Central Africa can still be treated as a single species.

Two filters, encounter and parasite-host compatibility, delimit the host specificity of parasites (Combes 1991). All three studied host species share the environment extensively; thus, it is obviously the compatibility filter that defines the host specificity of Mammomonogamus. Although gorillas and elephants are phylogenetically distant species, they are both hind-gut fermenters with considerable diet overlap, including plant roots, stems, leaves and fruits from the same species (Blake 2002; Morgan and Lee 2007; Masi et al. 2009; Masi et al. 2012). As buffaloes are ruminants and grass represents the main part of their diet (Bekhuis et al. 2008), there is a significant difference in their feeding habits and the environment within their gastrointestinal 
tract. Although the life cycle of Mammomonogamus is not completely known, it is possible, that digestive physiology together with the dissimilarity of the respiratory tract morphology affects the transmission pattern of these helminths.

Our study revealed two putative species of Mammomonogamus found partly sympatric across the studied localities. However, assigning names to these taxa is complicated. Unfortunately, we did not obtain any adult helminths; nevertheless, the taxonomy of the African Mammomonogamus species is unclear anyway. Most taxonomic descriptions are rather vague and, except for M. nasicola, none of the named species has been recorded ever since. Although the description of M. loxodontis is also not very thorough (Vuylsteke 1935, Table 1), this name remains a plausible candidate applicable to the species infecting elephants and gorillas across Central Africa, as suggested previously (Červená et al. 2017). There are three other nominal species that should be considered in a quest for naming the Mammomonogamus in African forest buffaloes (M. nasicola, M. okapiae, and M. hippopotami). Mammomonogamus nasicola has already been recorded in forest buffalo in Central African Republic (Graber et al. 1971). When comparing its morphology description with M. okapiae, the measurements are almost identical (Table 1). As both species infect ruminants and are found basically in the same parts of respiratory tract, $M$. okapiae might represent a junior synonym of M. nasicola. The remaining species, M. hippopotami, differs in its morphology from its other congeners (e.g., double the size, different number of ribs) and remains another enigmatic member of the genus. Based on available evidence, we suggest the species of Mammomonogamus infecting forest buffaloes in LNP to be referred to as M. nasicola.

In conclusion, although the morphology of adult worms remains an important criterion for species discrimination, the DNA based taxonomy represents a suitable tool for accurate parasite identification. If the public sequence repositories contain sequences originating from morphologically determined adult helminths, the proper identification is possible even from a single egg. Nevertheless, even without adults, this approach allows the assessment of host specificity of parasitic helminths in multiple host systems. Our data proved existence of at least two distinct species of Mammomonogamus infecting the large herbivores of Central Africa, most probably M. loxodontis and M. nasicola. Mammomonogamus okapiae and M. hippopotami remain enigmatic species, and their status can only be assessed with new material. However, as okapis are critically endangered, parasite collection from these elusive forest herbivores represents an unquestionable challenge.

Acknowledgements We would like to thank the government of the Central African Republic, the World Wildlife Fund, the Ministère de l'Education Nationale, de l'Alphabétisation, de l'Enseignement Supérieur, et de la Recherche for granting permission and providing permits to conduct our research in the Central African Republic and the Primate Habituation Programme for logistical support in the field. We are thankful to the Centre National de la Recherche Scientifique et Technologique (CENAREST) and the Agence National des Parcs Nationaux (ANPN) for research authorization in Gabon. We thank SFM Safari Gabon for hosting our research and seeing the value of health monitoring as part of the development of ape tourism programs, especially to Matthew H. Shirley and Emilie Fairet as well as our field assistants Pierre Bukosso and Kharl Remanda for their significant support in the field. We express our thanks to the Ministère des Fôrets et de la Faune and Ministère de la Recherche Scientifique et de l'Innovation in Cameroon for permitting our research. We thank the Projet Grands Singes, Centre for Research and Conservation, Royal Zoological Society of Antwerp, and WWF Kudu-Zumbo Programme for providing their material and logistical support in the field. We would also like to thank all trackers and research assistants from all study sites, especially to Arlette Tchankugni Nguemfo and Charmance Irene Nkombou for helping with sample collection. We thank Jana Bulantová and her team from the Department of Parasitology, Faculty of Science, Charles University, Prague, for providing us with specimens of Syngamus sp. collected from a crow.

Funding information This work was supported by the Czech Science Foundation (15-05180S) and derived from the Laboratory for Infectious Diseases Common to Humans and (non-Human) Primates from Czech Republic (HPI-Lab) and was co-financed by the European Social Fund and the state budget of the Czech Republic (project OPVK CZ.1.07/ 2.3.00/20.0300). Further support came from "CEITEC"-Central European Institute of Technology (CZ.1.05/1.100/02.0068), the European Regional Development Fund, and The Institute of Vertebrate Biology, Czech Academy of Sciences (RVO: 68081766). The work was supported by project LO1218 with financial support from the Ministry of Education, Youth, and Sports of the Czech Republic under the NPU I program. We acknowledge a grant for the development of research organization (RVO: RO0516).

\section{References}

Bekhuis PDBM, De Jong CB, Prins HHT (2008) Diet selection and density estimates of forest buffalo in Campo-Ma'an National Park, Cameroon. Afr J Ecol 46(4):668-675. https://doi.org/10.1111/j. 1365-2028.2008.00956.x

Blake S (2002) The ecology of forest elephant distribution and its implication for conservation. Dissertation University of Edinburgh

Blake S, Strindberg S, Boudjan P, Makombo C, Bila-Isia I, Ilambu O, Grossmann F, Bene-Bene L, de Semboli B, Mbenzo V, S'hwa D, Bayogo R, Williamson L, Fay M, Hart J, Maisels F (2007) Forest elephant crisis in the Congo Basin. PLoS Biol 5(4):e111. https://doi. org/10.1371/journal.pbio.0050111

Blouin MS (2002) Molecular prospecting for cryptic species of nematodes: mitochondrial DNA versus internal transcribed spacer. Int J Parasitol 32(5):527-531. https://doi.org/10.1016/S0020-7519(01) 00357-5

Blouin MS, Yowell CA, Courtney CH, Dame JB (1998) Substitution bias, rapid saturation, and the use of mtDNA for nematode systematics. Mol Biol Evol 15:1719-1727

Budischak SA, Jolles AE, Ezenwa VO (2012) Direct and indirect costs of co-infection in the wild: linking gastrointestinal parasite communities, host hematology and immune function. Int J Parasitol Parasites Wildl 1:2-12. https://doi.org/10.1016/j.ijppaw.2012.10.001

Červená B, Vallo P, Paf̌co B, Jirků K, Jirků M, Petrželková KJ, Todd A, Turkalo AK, Modrý D (2017) Host specificity and basic ecology of Mammomonogamus (Nematoda, Syngamidae) from lowland gorillas and forest elephants in Central African Republic. Parasitology 144(08):1-10. https://doi.org/10.1017/ S0031182017000221 
Chilton NB, Huby-Chilton F, Gasser RB (2003) First complete large subunit ribosomal RNA sequence and secondary structure for a parasitic nematode: phylogenetic and diagnostic implications. Mol Cell Probes 17(1):33-39. https://doi.org/10.1016/S0890-8508(02) 00107-X

Chilton NB, Huby-Chilton F, Gasser RB, Beveridge I (2006) The evolutionary origins of nematodes within the order Strongylida are related to predilection sites within hosts. Mol Phylogenet Evol 40:118-128. https://doi.org/10.1016/j.ympev.2006.01.003

Clifford SL, Anthony NM, Bawe-Johnson M, Abernethy KA, Tutin CE, White LJ, Bermejo M, Goldsmith ML, McFarland K, Jeffery KJ, Bruford MW, Wickings EJ (2004) Mitochondrial DNA phylogeography of western lowland gorillas (Gorilla gorilla gorilla). Mol Ecol 13(6):1551-1565. https://doi.org/10.1111/j. 1365-294X.2004.02140.x

Combes C (1991) Evolution of parasite life cycles. In: Toft CA, Aeschlimann A, Bolis L (eds) Parasite-host associations: coexistence or conflict? Oxford University Press, Oxford, pp 62-82

Cooper N, Griffin R, Franz M, Omotayo M, Nunn CL (2012) Phylogenetic host specificity and understanding parasite sharing in primates. Ecol Lett 15(12):1370-1377. https://doi.org/10.1111/j. 1461-0248.2012.01858.x

Folmer O, Black M, Hoeh W, Lutz R, Vrijenhoek R (1994) DNA primers for amplification of mitochondrial cytochrome c oxidase subunit I from diverse metazoan invertebrates. Mol Mar Biol Biotechnol 3: 294-299

Freeman AS, Kinsella JM, Cipoletta C, Deem SL Karesh WB (2004) Endoparasites of western lowland gorillas (Gorilla gorilla gorilla) at Bai Hokou, Central African Republic. J Wildl Dis 40(4):775-781. https://doi.org/10.7589/0090-3558-40.4.775

Fünfstück T, Arandjelovic M, Morgan DB, Sanz C, Breuer T, Stokes EJ, Reed P, Olson SH, Cameron K, Ondzie A, Peeters M, Kühl HS, Cipoletta C, Todd A, Masi S, Doran-Sheehy DM, Bradley BJ, Vigilant L (2014) The genetic population structure of wild western lowland gorillas (Gorilla gorilla gorilla) living in continuous rain forest. Am J Primatol 76(9):868-878. https://doi.org/10.1002/ajp. 22274

Fünfstück T, Vigilant L (2015) The geographic distribution of genetic diversity within gorillas. Am J Primatol 77(9):974-985. https://doi. org/10.1002/ajp.22427

Gedoelst L (1924) Un syngame parasite de l'hippopotame. Ann Parasitol 2(4):307-311. https://doi.org/10.1051/parasite/1924024307

Ghesquière J (1934) Sur la répartition géographique de deux vers syngames observés au Congo Belge. C R Somm Séanc Soc Biogéogr 89:10-12

Graber M, Euzeby J, Gevrey J, Troncy PM, Thal J (1971) La mammomonogamose des ruminants domestiques et sauvages. Rev Élev Méd Vét Pays Trop 24(4):525-541. https://doi.org/10.19182/ remvt.7717

Graber M, Euzeby J, Gevrey J, Troncy PM (1972) Les Mammomonogamus des ruminants domestiques et sauvages. Ann Parasitol 47(2):225-241. https://doi.org/10.1051/parasite/ 1972472225

Hall TA (1999) BioEdit: a user-friendly biological sequence alignment editor and analysis program for Windows 95/98/NT. Nucleic Acids Symp Ser 41:95-98

Hasegawa H, Modrý D, Kitagawa M, Shutt KA, Todd A, Kalousová B, Profousová I, Petrželková KJ (2014) Humans and great apes cohabiting the forest ecosystem in Central African Republic harbour the same hookworms. PLoS Negl Trop Dis 8(3):e2715. https://doi.org/ 10.1371/journal.pntd.0002715

Hastings WK (1970) Monte Carlo sampling methods using Markov chains and their applications. Biometrika 57(1):97-109. https://doi. org/10.1093/biomet/57.1.97

Head JS, Boesch C, Robbins MM, Rabanal LI, Makaga L, Kühl HS (2013) Effective sociodemographic population assessment of elusive species in ecology and conservation management. Ecol Evol 3(9):2903-2916. https://doi.org/10.1002/ece3.670

Herd RP (1986) Serum pepsinogen concentrations of ponies naturally infected with Trichostrongylus axei. Equine Vet J 18(6):490-491. https://doi.org/10.1111/j.2042-3306.1986.tb03700.x

Hu M, Chilton NB, Zhu XQ, Gasser RB (2002) Single-strand conformation polymorphism-based analysis of mitochondrial cytochrome $\mathrm{c}$ oxidase subunit 1 reveals significant substructuring in hookworm populations. Electrophoresis 23(1):27-34. https://doi.org/10.1002/ 1522-2683(200201)23:1<27::AID-ELPS27>3.0.CO;2-7

Ishida Y, Georgiadis NJ, Hondo T, Roca AL (2013) Triangulating the provenance of African elephants using mitochondrial DNA. Evol Appl 6(2):253-265. https://doi.org/10.1111/j.1752-4571.2012. 00286.x

Jirků-Pomajbíková K, Hůzová Z (2015) Coproscopic techniques. In: Modrý D, Petrželková KJ, Kalousová B, Hasegawa H (eds) Parasites of African great apes: atlas of coproscopic diagnostics. HPI-lab, Department of Pathology and Parasitology, University of Veterinary and Pharmaceutical Sciences Brno, Brno, Czech Republic, pp 14-24

Johnson PTJ, de Roode JC, Fenton A (2015) Why infectious disease research needs community ecology. Science: New York, 349: 1259504. https://doi.org/10.1126/science. 1259504

Kearse M, Moir R, Wilson A, Stones-Havas S, Cheung M, Sturrock S, Buxton S, Cooper A, Markowitz S, Duran C, Thierer T, Ashton B, Mentjies P, Drummond A (2012) Geneious basic: an integrated and extendable desktop software platform for the organization and analysis of sequence data. Bioinformatics 28(12):1647-1649. https:// doi.org/10.1093/bioinformatics/bts199

Kinsella JM, Deem SL, Blake S, Freeman AS (2004) Endoparasites of African forest elephant (Loxodonta africana cyclotis) from the Republic of Congo and Central African Republic. Comp Parasitol 71(2):104-110. https://doi.org/10.1654/4131

Larkin MA, Blackshields G, Brown NP, Chenna R, McGettigan PA, McWilliam H, Valentin F, Wallace IM, Wilm A, Lopez R, Thompson JD, Gibson TJ, Higgins DG (2007) ClustalW and ClustalX version 2.0. Bioinformatics (Oxf) 23:2947-2948

Maisels F, Strindberg S, Blake S, Wittemyer G, Hart J, Williamson EA, Aba'a R, Abitsi G, Ambahe RD, Amsini F, Bakabana PC, Hicks TC, Bayogo RE, Bechem M, Beyers RL, Bezangoye AN, Boundja P, Bout N, Akou ME, Bene LB, Fosso B, Greengrass E, Grossmann F, Ikamba-Nkulu C, Ilambu O, Inogwabini BI, Iyenguet F, Kiminou F, Kokangoye M, Kujirakwinja D, Latour S, Liengola I, Mackaya Q, Madidi J, Madzoke B, Makoumbou C, Malanda GA, Malonga R, Mbani O, Mbendzo VA, Ambassa E, Ekinde A, Mihindou Y, Morgan BJ, Motsaba P, Moukala G, Mounguengui A, Mowawa BS, Ndzai C, Nixon S, Nkumu P, Nzolani F, Pintea L, Plumptre A, Rainey H, de Semboli BB, Serckx A, Stokes E, Turkalo A, Vanleeuwe H, Vosper A, Warren Y (2013) Devastating decline of forest elephants in Central Africa. PLoS One 8(3):e59469. https:// doi.org/10.1371/journal.pone.0059469

Martin C, Pastoret PP, Brochier B, Humblet MF, Saegerman C (2011) A survey of the transmission of infectious diseases/infections between wild and domestic ungulates in Europe. Vet Res 42(1):70. https:// doi.org/10.1186/1297-9716-42-70

Masi S, Cipoletta S, Robbins MM (2009) Western lowland gorillas (Gorilla gorilla gorilla) change their activity patterns in response to frugivory. Am J Primatol 71(2):91-100. https://doi.org/10.1002/ ajp. 20629

Masi S, Gustafsson E, Saint Jalme M, Narat V, Todd A, Bomsel M-C, Krief S (2012) Unusual feeding behavior in wild great apes, a window to understand origins of self-medication in humans: role of sociality and physiology on learning process. Physiol Behav 105(2):337-349. https://doi.org/10.1016/j.physbeh.2011.08.012

Miranda RR, Tennessen JA, Blouin MS, Rabelo ÉM (2008) Mitochondrial DNA variation of the dog hookworm Ancylostoma 
caninum in Brazilian populations. Vet Parasitol 151(1):61-67. https://doi.org/10.1016/j.vetpar.2007.09.027

Morgan BJ (2007) Group size, density and biomass of large mammals in the Réserve de Faune du Petit Loango, Gabon. Afr J Ecol 45(4): 508-518. https://doi.org/10.1111/j.1365-2028.2007.00761.x

Morgan BJ, Lee PC (2007) Forest elephant group composition, frugivory and coastal use in the Réserve de Faune du Petit Loango, Gabon. Afr J Ecol 45(4):519-526. https://doi.org/10.1111/j.1365-2028.2007. 00762.x

Opasina BA, Dipeolu OO (1983) Fatal infection of a West African dwarf sheep with Mammomonogamus nasicola (S. Syngamus nasicola). Zbl Vet Med B 30:313-315

Posada D, Crandall KA (1998) Modeltest: testing the model of DNA substitution. Bioinformatics 14(9):817-818. https://doi.org/10. 1093/bioinformatics/14.9.817

Poulin R (2007a) Host specificity. In: Poulin R (ed) Evolutionary ecology of parasites, 2nd edn. Princeton University Press, Princeton, pp 4169

Poulin R (2007b) Are there general laws in parasite ecology? Parasitology 134(06):763-776. https://doi.org/10.1017/S0031182006002150

Poulin R, Keeney DB (2008) Host specificity under molecular and experimental scrutiny. Trends Parasitol 24(1):24-28. https://doi.org/ 10.1016/j.pt.2007.10.002

Rabanal LI, Kuehl HS, Mundry R, Robbins MM, Boesch C (2010) Oil prospecting and its impact on large rainforest mammals in Loango National Park, Gabon. Biol Conserv 143(4):1017-1024. https://doi. org/10.1016/j.biocon.2010.01.017

Ronquist F, Huelsenbeck JP (2003) MrBayes 3: Bayesian phylogenetic inference under mixed models. Bioinformatics 19(12):1572-1574. https://doi.org/10.1093/bioinformatics/btg180

Sachs R, Debbie JG (1969) A field guide to the recording of parasitic infestation of game animals. Afr J Ecol 7:27-37

Sachs R, Frank H, Bindernagel JA (1969) New host records for Mammomonogamus in African game animals through application of a simple method of collection. Vet Rec 84:562-563

Sachs R, Sachs C (1968) A survey of parasitic infestation of wild herbivores in the Serengeti region in Northern Tanzania and the Lake Rukwa region in Southern Tanzania. Bull Epizoot Dis Afr 16(4): 455-472

Setchel JM, Bedjabaga IB, Goossens B, Reed P, Wickings EJ, Knapp LA (2007) Parasite prevalence, abundance, and diversity in a semi-freeranging colony of Mandrillus sphinx. Int J Primatol 28(6):13451362. https://doi.org/10.1007/s10764-007-9225-6

Sheather AL (1923) The detection of intestinal protozoa and mange parasites by a flotation technique. J Comp Pathol Ther 36:266-275. https://doi.org/10.1016/S0368-1742(23)80052-2

Standley CJ, Mugisha L, Adriko M, Arinaitwe M, Rukundo J, Ajarova L, Mopya S, Betson M, Kabatereine NB, Stothard JR (2013) Intestinal schistosomiasis in chimpanzees on Ngamba Island, Uganda: observations on liver fibrosis, schistosome genetic diversity and praziquantel treatment. Parasitology 40(03):285-295. https://doi. org/10.1017/S0031182012001576

Streicker DG, Fenton A, Pedersen AB (2015) Corrigendum to Streicker et al. (2013) Differential sources of host species heterogeneity influence the transmission and control of multi-host parasites. Ecol Lett 18(10):1134-1137. https://doi.org/10.1111/ele.12477

Strimmer K, von Haeseler A (1997) Likelihood-mapping: a simple method to visualize phylogenetic content of a sequence alignment. Proc Natl Acad Sci U S A 94(13):6815-6819. https://doi.org/10.1073/ pnas.94.13.6815

Telfer S, Lambin X, Birtles R, Beldomenico P, Burthe S, Paterson S, Begon $M$ (2010) Species interactions in a parasite community drive infection risk in a wildlife population. Science 330(6001):243-246. https://doi.org/10.1126/science.1190333

Tchouto MGP (2004) Plant diversity in a central African rain forest: implications for biodiversity conservation in Cameroon. Dissertation, Wageningen University

Traversa D, Kuzmina T, Kharchenko VA, Iorio R, Klei TR, Otranto D (2008) Haplotypic variability within the mitochondrial gene encoding for the cytochrome $c$ oxidase ( $\operatorname{coxl}$ ) of Cylicocyclus nassatus (Nematoda, Strongylida): evidence for an affiliation between parasitic populations and domestic and wild equid hosts. Vet Parasitol 156(3-4):241-247. https://doi.org/10.1016/j.vetpar. 2008.05.031

van den Berghe L (1937) Contribution à l'etude des parasites de l'okapi. Rev Zool Bot Afr 29:141-150

Vercruysse J (1978) La mammomonogamose des zébus en empire centrafrican. Rev Élev Méd Vét Pays Trop 31(4):427-430. https:// doi.org/10.19182/remvt.8113

von Linstow O (1899) Nematoden aus der Berliner Zoologischen Sammlung. Mitt Zool Mus Berl 1:1-28

Vuylsteke C (1935) Etude de quelques nématodes parasites de l'éléphant. Rev Zool Bot Afr 27:319-325

Walker GJ, Plein M, Morgan ER, Vesk PA (2017) Uncertain links in host-parasite networks: lessons for parasite transmission in a multi-host system. Phil Trans R Soc B 372(1719):20160095. https://doi.org/10.1098/rstb.2016.0095

Webster JP, Borlase A, Rudge JW (2017) Who acquires infection from whom and how? Disentangling multi-host and multi-mode transmission dynamics in the 'elimination' era. Phil Trans R Soc B 372(1719):20160091. https://doi.org/10.1098/rstb.2016.0091

Willie J, Petre CA, Tagg N, Lens L (2012) Density of herbaceous plants and distribution of western gorillas in different habitat types in south-east Cameroon. Afr J Ecol 51(1):111-121. https://doi.org/10. 1111/aje.12014

Willie J, Tagg N, Petre CA, Pereboom Z, Lens L (2013) Plant selection for nest building by western lowland gorillas in Cameroon. Primates 55(1):41-49. https://doi.org/10.1007/s10329-013-0363-5

Woolhouse MEJ, Taylor LH, Haydon DT (2001) Population biology of multihost pathogens. Science 292(5519):1109-1112. https://doi.org/ 10.1126/science. 1059026 